\title{
Which conservatism? The identity of the Polish Law and Justice party ${ }^{1}$
}

\author{
Adam Folvarčný and Lubomír Kopeček
}

\section{sciendo}

Politics in Central Europe (ISSN: 1801-3422)

Vol. 16, No. 1

DOI: 10.2478/pce-2020-0008

\begin{abstract}
This article deals with Poland's Law and Justice (PiS), considered a conservative party in the scholarly literature. Drawing largely on party manifestos, the article demonstrates the character, the specificities and the evolution of the party's identity and ideology. A theoretical basis for the undertaking is provided by Klaus von Beyme's concept of party families, Arend Lijphart's seven ideological dimensions and classic texts on conservatism. The analysis finds that the most important components in PiS's current identity are Catholicism itself and the great emphasis the party places on the role of the Catholic Church. Also important for the party's identity are visions of a nation conceived on ethnic principle, a strong and active state able to form society with a national spirit, anti-communism and a negation of developments in Poland since 1989. A substantial role is played by the quasi-religiously conceived legacy of the party's co-founder, Lech Kaczyński, who tragically perished in an aircraft crash. With its Catholic-nationalist profile, PiS is close to the Christian current within the conservative New Right, and to Polish National Democracy in the interwar period.
\end{abstract}

Keywords: the Law and Justice party, PiS, Jarosław and Lech Kaczyński, Catholicism, nationalism, the Smolensk crash, anti-communism

1 This publication was written at Masaryk University with the support of the Specific University Research Grant provided by the Ministry of Education, Youth and Sports of the Czech Republic. The authors would like to thank anonymous referees for their useful comments and Štěpán Káňa for the translation of the text. 


\section{Introduction}

There are not many political parties that have radically changed the life of their country within a few years. Undisputedly, the Polish Law and Justice party (Prawo i Sprawiedliwość, PiS) contrived to do just this. Thanks to radical transformations in the judiciary, media, education and culture, today's Poland is in many respects a different country than in 2015, when PiS won the parliamentary elections and formed a single-party government. ${ }^{2}$ Some authors even argue that the foundations of a new political regime have been laid down. Although they differ in how they classify it, it is evident that this is no longer a liberal democracy (e.g. Sadurski 2018, 2019; Markowski 2019). In the 2019 elections, PiS confirmed its dominance of Polish politics, improving on its result four years previously.

In seeking the roots of this dramatic change of Poland, we need to analyse the PiS ideological profile and identity, which is the aim of this article. We first present our theoretical and conceptual points of departure and formulate the two fundamental questions we seek to answer. This is followed by an excursus on historical Polish conservatism, the context in which PiS emerged, its development and its founding fathers, Jarosław and Lech Kaczyński. At the core of the article PiS is analysed in the major ideological dimensions.

\section{Party identity and conservatism as an ideology}

This article proceeds from the premise that $\mathrm{PiS}$ is a conservative party. This is the prevailing opinion in literature on Polish politics (e.g. Dančák 2002: 302-304; Kubát 2005: 104; Kowalczyk and Sielski 2005: 168; Szczerbiak 2006a: 96; Wojtaszczyk 2007: 91). However, the character and specifics of this conservatism are rarely analysed systematically. Our first research question, therefore, is projected into the very title of this article: What sort of conservatism does PiS embrace? We take our inspiration from Klaus von Beyme's (1985) concept of party families, which is a useful instrument not just for Western politics but also for East-Central Europe (Hloušek and Kopeček 2010; Gallagher, Laver and Mair 2011). Beyme reflects the origin and the evolution of the given party, which influence its identity, and pays even greater attention to how its values and ideas are projected into party documents. This reflects his understanding of ideology as the key pillar of the party family, and this includes the conservatives. ${ }^{3}$ For our analysis, we use - in accordance with von Beyme's approach party documents and secondary literature, a common methodological approach

\footnotetext{
2 Politicians of two other tiny right-wing parties, who stood for election on the PiS ticket, were involved in governance, so formally it was not a pure single-party government. However, PiS was so dominant in this political arrangement that we can abstract from this quasi-coalition aspect for simplicity's sake.

3 For reasons of space we omit the frequently discussed question: Is conservatism truly an ideology?
} 
(e.g. Hendl 2008: 130-131). ${ }^{4}$ This allows us to examine the ideological dynamics of PiS, that is, to answer the following question: How did the party's ideology develop over time, if it did develop at all? This second research question is justified by the fact that nearly two decades have now elapsed since the foundation of PiS. We understand ideology in line with Peter Mair and Cas Mudde (1998: 220) as 'a belief system that goes right to the heart of a party's identity'.

It is, however, impossible to identify a 'single' conservatism, because understandings of this concept differ. This is connected with the extensive changes and development of conservatism over the past two centuries. Among other things, von Beyme attributes this to the transforming social base of its supporters. Originally, conservatism's stronghold was the nobility and clergy, moving to the upper middle class in the 19th century, only to be embraced in the 20th even by the working classes. This development was influenced by the weakening of the original class structure of European societies, as well as by increasing social mobility (Beyme 1985: 52; cf. Scruton 1993: 58).

In order to understand the genesis of conservatism, we need briefly to outline its two fundamental historical traditions, as they established themselves in the 18th and 19th centuries: the British one and the authoritarian-continental one. Both responded to the challenge of the French Revolution and the critique of this revolution. Essential for the former was its drawing on the traditions of the British Tory party and its development, with an emphasis on paternalism, moderation and adaptation, including the gradual acceptance of mass democracy. Its key thinker was Edmund Burke, and the successful practical implementers of the reform included Benjamin Disraeli (Heywood 2007: 82-83). By contrast, the second, continental European tradition tended towards authoritarian notions and solutions. Characteristic were the opinions of Joseph de Maistre, who rejected reform and defended absolute monarchy and the principles of the ancien régime. Connected with this was a vigorous denial of the revolutionary abandonment of religion, and of seeking human happiness via political action (O'Sullivan 2013: 294). Unlike with religiously moderate Anglo-Saxon conservatism, God and dogmatism were the focal points of de Maistre's conservatism. Imperial Germany and especially Chancellor Otto von Bismarck - the creator of the first backgrounds of the welfare state - provided inspiration for the political practice of the authoritarian-continental branch of conservatism. Yet the fact that in Germany it combined with nationalism, militarism and, to a certain extent, anti-Semitism, proved destructive for this conservatism. David Allen (1981: 591) points out that these conservatives admired war, seeing it as an institution with a vitalising character. In the closing years of the Weimar democracy, in the early 1930s, this led German conservatives to collaborate with

4 We include government declarations and other materials from the period of the single-party PiS government after 2015 among party documents. 
the Nazis, compromising with them after 1945. Something similar happened in France, where implacable anti-republicanism led the conservatives towards extreme-right positions.

Thus the British version of conservatism, accepting democracy, became much more important for the prevailing future understanding of the ideology. But this conservatism evolved too as the United Kingdom changed. First, under the influence of a social shift to the left after World War II, the Conservatives came close to Labour in their economic interventionism. This created a counter-reaction in the last quarter of the 20th century, with a wave of anti-statist and anti-progressivist conservatism. Some representatives of this New Right, as this strand of conservatism has been called, in the zeal of their pro-market orientation even came to reject some of the classic conservative premises. Beyond patriotism, order and hierarchy - common with conservatives - British Prime Minister Margaret Thatcher also emphasised individualism and denied the importance of society, contradicting one of the fundamental values of this ideology.

Let us try to delimit - albeit somewhat eclectically - the fundamental characteristics of the conception of conservatism that currently prevails in Europe, as this will allow us to note the specifics of PiS. We proceed from the Anglo-Saxon understanding, largely linked with Britain, but have no ambition to 'standardise' the understanding of conservatism. In order to provide a synoptic overview, we use the seven ideological dimensions, in which, according to Arend Lijphart (1990: 253-265), party-political views of politics clash with each other. These dimensions, outlined alongside a commentary in Table 1, allow us to undertake a systematic analysis of the PiS ideology and core identity.

Naturally, the chosen approach has its limits. A focus on these generalised dimensions implies simplification of what is after all a more complex image of party identity. It is also worth noting that an analysis largely of party documents cannot access some important aspects, for instance, a certain heterogeneity in PiS which is due to the colourful spectrum of its cadres. Despite these limitations, our approach allows us to capture the main characteristics of PiS relatively faithfully. 


\section{Table 1: The conservative view of the world, according to Arend Lijphart's dimensions}

\begin{tabular}{|c|c|c|}
\hline Dimension & Key issues & Conservative positions and manifestations \\
\hline $\begin{array}{l}\text { Socio- } \\
\text {-economic }\end{array}$ & $\begin{array}{l}\text { Type of property, } \\
\text { redistribution of resources } \\
\text { and social programmes }\end{array}$ & $\begin{array}{l}\text { - Largely aim to have a state that cares for the public } \\
\text { sphere, but with limited powers. } \\
\text { - An emphasis on the free market, but with } \\
\text { a mediating and regulating role for the state; the } \\
\text { degree of admissibility of state intervention differs } \\
\text { from party to party, as does the extent of social } \\
\text { programmes, which nevertheless always provide } \\
\text { a certain basic minimum. } \\
\text { - Vigorous support for private ownership, protection } \\
\text { of property and the autonomy of the private sphere. }\end{array}$ \\
\hline Religious & $\begin{array}{l}\text { Position on religious values } \\
\text { linked with politics; related } \\
\text { issues of marriage, divorce, } \\
\text { abortion etc. }\end{array}$ & $\begin{array}{l}\text { - Church and religion are central to society and } \\
\text { important for its functioning. } \\
\text { - Religious beliefs should not be imposed. } \\
\text { - Natural groups of belonging constitute the basis, } \\
\text { which forms people; these include, beyond families, } \\
\text { parishes and the Church in general. } \\
\text { - On related issues, traditional views are preferred and } \\
\text { liberalisation is rejected. }\end{array}$ \\
\hline $\begin{array}{l}\text { Cultural } \\
\text { and ethnic }\end{array}$ & $\begin{array}{l}\text { National homogeneity and } \\
\text { position on minorities }\end{array}$ & $\begin{array}{l}\text { - Frequent emphasis on the importance of the nation, } \\
\text { linked with patriotism; reserve towards radical } \\
\text { nationalism. } \\
\text { - An understanding of the nation based on shared } \\
\text { history, traditions and a sense of belonging prevails. } \\
\text { - The approach to minorities is not arbitrary, but may } \\
\text { be restrictive; restraint towards or rejection of the } \\
\text { enlargement of minority rights and multiculturalism. }\end{array}$ \\
\hline $\begin{array}{l}\text { Support for } \\
\text { the regime }\end{array}$ & $\begin{array}{l}\text { Idea of a political regime and } \\
\text { calls for its change, type of } \\
\text { government }\end{array}$ & $\begin{array}{l}\text { - Opposition to reforming and universalist liberalism, } \\
\text { rejection of the idea of unlimited human rationality. } \\
\text { - People should proceed on the basis of experience, } \\
\text { which is accumulated in tradition (and is revealed in } \\
\text { history). } \\
\text { - The state should be sufficiently strong and maintain } \\
\text { its authority vis-à-vis the hierarchical society, but } \\
\text { authority and leadership are not unlimited in } \\
\text { character. } \\
\text { - Separation of powers with an emphasis on judicial } \\
\text { independence. }\end{array}$ \\
\hline $\begin{array}{l}\text { Urban vs. } \\
\text { rural }\end{array}$ & $\begin{array}{l}\text { Promotion of the interests } \\
\text { and lifestyle of one or the } \\
\text { other }\end{array}$ & $\begin{array}{l}\text { - Support for business and a separation between } \\
\text { urban and rural areas (not necessarily strict). } \\
\text { - The electoral stronghold of the party in the one or } \\
\text { the other type of area may exert an influence. }\end{array}$ \\
\hline
\end{tabular}




\begin{tabular}{|l|l|l|}
\hline Dimension & Key issues & Conservative positions and manifestations \\
\hline $\begin{array}{l}\text { Foreign } \\
\text { policy }\end{array}$ & $\begin{array}{l}\text { Position on Euro-Atlantic } \\
\text { structures and international } \\
\text { orientation }\end{array}$ & $\begin{array}{l}\text { - Support for the principles and interests of the nation } \\
\text { state with an emphasis on patriotism, protection of } \\
\text { borders and preservation of national identity. } \\
\text { - An accommodating position on NATO, support for } \\
\text { EU membership but in a pragmatic understanding, } \\
\text { without Eurofederalist ambitions. }\end{array}$ \\
\hline $\begin{array}{l}\text { Post- } \\
\text {-materialist* }\end{array}$ & $\begin{array}{l}\text { Position on economic growth } \\
\text { and environmentalism, } \\
\text { importance of the } \\
\text { environment, centralisation } \\
\text { and participation }\end{array}$ & $\begin{array}{l}\text { - Rejection of 'environmentalist ideology'. } \\
\text { - Aim for a balance between the demands of growth } \\
\text { and environmental protection; the environment is not } \\
\text { to suffer from radical devastation, yet everything else } \\
\text { should not be subordinated to care for the planet. } \\
\text { - Increased attention to environmental issues might be } \\
\text { linked with the party's specific identity. }\end{array}$ \\
\hline
\end{tabular}

Sources: Lijphart 1990; conservatism is outlined according to Scruton 1993; Heywood 2007; Hecke 2008; Šmíd 2008; Vincent 2010; Nisbet 2011.

* Post-materialism is usually understood more broadly, with an emphasis on toleration of various minorities, alternative lifestyles etc. - issues we discuss in connection with other dimensions.

\section{Polish conservatism and the Kaczyński brothers}

Like almost everywhere else in Europe, the beginnings of conservatism in Poland are linked with the aristocracy. However, its character was strongly influenced by the division of the country between Austria, Russia and Prussia (later Germany), which lasted until World War I. This division contributed to the great political fragmentation of the aristocratic conservatives, and created the problem of their positions towards these powers. Loyalty to the monarchythe form of government of all three powers - clashed with the aristocratic conservatives' aspiration to renew Poland as an independent state. The result was paradoxical: proximity to the continental conservative tradition, combined with (frequent) opposition towards the existing conservative political system. The Austrian, Prussian and Russian political regimes, nevertheless, were different in character. The aristocratic conservatives could therefore also opt for a close symbiosis with the existing regime - as was the case in Galicia, the Austrian part of Poland, in the decades before World War I (Nałęcz 1994: 138-139).

The complicated dilemmas faced by the aristocratic conservatives and their narrow class-based outlook played into the hands of the expansion of another conservative force, the National Democrats, whose main political and spiritual father was Roman Dmowski. Unlike the exclusive aristocratic conservatives, the National Democrats (commonly called endecja in Poland) were a mass movement, and a relatively heterogeneous political camp. Generally it was true that they entirely subjected individual values to the collective national interest - the 
renewal of the Polish state. This was accompanied by a negation of liberalism, seen as a threat to the national idea; in combination with nationalism, national solidarism and, often, anti-Semitism.

Once Poland was renewed in 1918 - an effort to which Dmowski made a significant contribution - the National Democrats showed at best reserve towards the new democratic regime, and in the worse case, resisted it. The extreme National Democrats sometimes used violence against their political opponents and initiated anti-Jewish pogroms. Remarkably, thanks to Dmowski, Catholicism became a stronger influence in the party identity, even though he himself had previously been cold towards it. This shift was influenced by the strong interweaving of Catholicism and national identity, which occurred over the last decades of the divided Poland. In the era before 1918, the Catholic Church was the only uniting national institution, and the clergy naturally became the agents of patriotic agitation and activism. Concurrently in Prussia/Germany and Russia, the anti-Polish repression hit the Catholic Church, thus paradoxically strongly cementing the model or stereotype of the Catholic Pole (e.g. Łuczewski 2016).

Beyond Catholicism, the National Democrats in the 1920s emphasised autarky and a vision of strongman politics inspired by fascist Italy (Wapiński 1989: 356; Lukowski and Zawadski 2003: 217). However, it was not the National Democrats but Marshal Józef Piłsudski who destroyed Polish democracy in 1926. Paradoxically, it was fear of the National Democrats' excesses that helped to bring his authoritarian regime into the power.

Although the National Democrats were not among the forces who collaborated with the Nazis during World War II, this did not save the party after 1945. During the construction of the communist regime, conservatives and conservative thought were marginalised. Although there were some attempts later to reactivate conservative groups, most of whom more or less endorsed the national-democratic tradition, until the late 1980s conservatism was largely limited to a means of intellectually escaping the official communist line (Matyja 2009: 50-54, 2015: 204-205).

The protagonists of the later PiS, the almost indistinguishable twins Jarosław and Lech Kaczyński, became involved in opposition activities at the turn of the 1960 s and 1970s. For many years, the mass trade union Solidarity, which the communist regime had to legalise in August 1980 due to the pressure created by extensive strikes, served as their political platform. Although a year-and-a-half later the government introduced martial law, Solidarity survived the subsequent years by going underground. Testifying to how the communist regime saw the Kaczyńskis is the fact that from late 1981 Lech was jailed for ten months for his activities.

Neither brother was a key figure in Solidarity until 1989, although they were not politically unimportant. Thus they did not have a major influence on the course and the results of the roundtable talks in early 1989, which de facto 
brokered a compromise between the Communists and Solidarity. The roundtable allowed semi-competitive elections and ensured the Polish transition to democracy. But at the same time, it served the brothers Kaczyński (and others) as a reason for criticism, and a point against which they defined their subsequent political careers. In their interpretation, the liberal-left wing of Solidarity betrayed the idea of a complete break with the communist regime (Dudek 1997: 25-27 and 30-60; Matyja 2009: 72-74 and 78-79; cf. Araloff 2005; New Internationalist 2007; Łątkowska and Borowski 2016a, 2016b; Foy and Wasik 2016).

The growing influence of the two brothers after summer 1989 was ensured by their alliance with the Solidarity leader, Lech Wałesa. When Solidarity fell apart in 1990, they used their new party, Centre Agreement (PC), to help elect Wałesa as Polish president. Jarosław became the chief of his office (Mlejnek 2011: 195). But as early as 1991, the brothers parted ways with Wałesa, disappointed that the idea of radical decommunisation would not be put into effect. Jarosław later described his support for Wałesa in the presidential election as his greatest political mistake (Karnowski and Zaremba 2006: 209; Szczerbiak 2006b: 61).

There were multiple factions in the Centre Agreement and the party's ideological orientation was relatively broad, though it placed strong emphasis on conservative values. In the Polish context, this was a logical step, not least because of the pre-communist past, when the Polish and Catholic identities were blended together, as noted above. During the communist era, Christianity and the Catholic Church served important roles as bases of anti-regime resistance, and the efforts of the Polish Communists to introduce atheism failed. The social authority of the Church was particularly strengthened by the election of Pope John Paul II, who was a Pole. At a time when most of the continent - including Western Europe - experienced a strong secularisation trend, Poland went its own way. The Polish right - of which the Centre Agreement was a part - therefore naturally absorbed Christianity after 1989.

However, the organisational structure of the Centre Agreement was loose, and it only won seats in parliament in 1991. In the next elections in 1993, when a five-per-cent threshold first applied for the Sejm (the lower chamber), the party failed. This meant a temporary loss of political importance for the brothers. ${ }^{5}$ Though their party was involved in efforts to integrate the Polish right, they themselves did not play a major role in this. Their major political reboot came only with the appointment of Lech as justice minister during the reshuffle of Jerzy Buzek's right-wing cabinet in 2000. Lech enjoyed great popularity in office, largely thanks to his anti-corruption rhetoric, and this proved a major boon to PiS, which the brothers founded (Dudek 2016: 428; Subotić and Stankiewicz 2001).

5 In 1997, Jarostaw was elected to Parliament on behalf of the National Revival of Poland, but his relationship with the party was very unstable. In 1995, Lech was elected chair of the Supreme Audit Office. 
In the 2001 Sejm elections, PiS polled 9.5 per cent of the vote and, after a stint in opposition, went on to win the 2005 parliamentary elections, taking 27 per cent of the vote. Soon afterwards, Lech also won the presidential election. In 2006, Jarosław Kaczyński became prime minister, creating a remarkable political arrangement without parallel in Europe, in which the two most important offices of the state were occupied by two brothers. The government of the heterogeneous coalition involving PiS, the ultra-Catholic League of Polish Families and the agrarian-syndicalist Self-Defence was, however, unstable, and resulted in an early election being called for 2007. In this and the subsequent 2011 elections, PiS placed second, although it took around 30 per cent of the vote. Donald Tusk's Civic Platform (PO) was victorious, successfully employing a strategy of scaremongering about PiS, largely using references to the controversial PiS government of 2005-2007. This worked best on liberal voters. ${ }^{6}$

An important formative moment for PiS identity was the crash of a government aircraft in April 2010 near Smolensk, Russia. Among the nearly 100 victims - members of the Polish political and military elite - were Lech Kaczyński and his wife. Although the state funeral became a show of national unity, the disaster quickly started to influence relations between the two major political actors, PiS and PO, and their chairs, Jarosław Kaczyński and Donald Tusk, and also created discord in Polish society. This was much facilitated by the emotive dimension of the disaster, because the journey had been to honour the memory of the victims of the Katyn massacre, that is, Polish Army officers murdered in 1940 by the Soviet NKVD.

$\mathrm{PiS}$ rejects the official inquest into the causes of the Smolensk plane disaster and to this day seeks to prove that it was a murder of Polish leaders. It does not eschew conspiracy theories in its programme, claiming, with respect to relations with Russia, that there was 'evidence of secret and influential mechanisms of dependence' and 'total subordination of the investigation to the Russian side' (PiS 2014a). Thus, PiS rapidly 'turned the tragedy into a clear political symbol' (Osiecki 2010: 293). As the political scientist Vít Dostál aptly noted, the remembrance of the Smolensk tragedy 'became part of the PiS narrative and of the party's internal mythology' (Česká televize 2017).

The 'Smolensk element' in PiS identity is two-fold. First, it serves to create identity and to mobilise, employing symbolic aspects that verge on the quasi-religious (grand remembrance projects on the anniversary and the emphasis placed on memorials to the victims). This offers people the option of identifying themselves with a critique of the post-1989 political regime through an event that had an important social impact. Second, it is constantly updated, by emphasising various disputed aspects of the event, primarily by lending

6 For the debate about the divide into a liberal and a conservative Poland, see e.g. Szczerbiak 2006b, Koubek 2007 or Pospíchal 2017. 
support to various conspiracy theories, such as that there was an explosion on board the aeroplane. This is done with the intention of creating internal and external enemies of PiS and, ultimately, of Poland (PiS 2011b; Dudek 2016: 619; Newsweek Polska 2017).

In 2010, following his brother's death, Jarosław Kaczyński failed to win the presidential election, succumbing to a $\mathrm{PO}$ candidate. His popularity never matched that of his brother; what is more, many Poles mistrusted him (e.g. CBOS 2014 and 2015). For that reason, he eventually decided no longer to pursue major public office, and PiS was represented in the 2015 presidential and parliamentary elections by the younger, less polarising figures, Andrzej Duda and Beata Szydło. Yet Jarosław Kaczyński has remained crucial for the PiS internal operations, enjoying despite his advanced age unshakeable respect and authority. He is the strategist and chair of PiS. The fact that he totally controls the party is illustrated well by his sudden decision that Prime Minister Szydło should resign in autumn 2017. This decision was accepted by everyone without reservation, including the prime minister herself. According to the PiS statutes, the chair is an independent body of the party, directing its more important bodies as well as the parliamentary party. Kaczyński's speeches at party meetings are seen as the most important, despite the fact that the prime minister and president are both also members of the party (e.g. Kowalczyk and Sielski 2005: 164-167; Borowiec, Sobolewska-Myślik and Kosowska-Gąstoł 2016: 321; PiS 2016; Jasiewicz and Jasiewicz-Betkiewicz 2018: 132-134; BBC Monitoring 2018). ${ }^{7}$

\section{The founders' ideological conception for PiS}

At the beginning of its existence, PiS established an anti-establishment party profile, demanding the cleansing of Polish politics and rejecting the developments in Poland since the end of the communist regime (the Polish People's Republic, PRL). The party documents described the state of Polish democracy as 'post-communism' and declared their intention to change or even remove most of the institutions introduced after 1989. Thus PiS defined itself as an alternative that sought to depart from the post-communist tradition and to establish Poland on different foundations. In this context, the party's official proclamations to the effect that it did not wish to threaten what has been achieved by

7 It is worth noting that the ancient link between the PiS founders and the Solidarity trade union continues to be beneficial for the party today. The union, which remains influential, under the former chair Janusz Śniadek openly supported the Kaczyńskis' candidatures for president in 2005 and 2010. The current chair of Solidarity, Piotr Duda, regularly appears at various state ceremonies. An interlinking of the personnel is apparent: for example, Janusz Śniadek was elected a member of parliament for PiS in 2011, and similarly other trade-union figures won public offices thanks to PiS support. Although Solidarity officially denies that it has a link with the party of government, its positions towards the government are evaluated as very accommodating, in marked contrast to the previous governments led by the Civic Platform (Nizinkiewicz 2019; Woźniak 2019; Wprost 2010). 
the removal of PRL, seem contradictory. The objective of creating a different Poland de facto seems revolutionary; but this is moderated by the proclamation that changes would be pursued through parliament (PiS 2001a a 2001b). The parliamentary majority obtained in the 2015 elections allowed the party to embark in just such a fashion.

The initial points of departure of the party programme were largely linked with the anti-communist proclamations by which PiS sought to define itself in opposition to the PRL period, the legacies of which were seen as the source of current problems. In its founding manifesto of 2001, the party did not openly avow any political or historical tradition, bar anti-communism. Yet it positively noted the periods and actions described as 'heroic'. These were, specifically, the interwar Second Polish Republic (1918-1939), the struggle against German and Soviet oppression, and the activities of Solidarity. In foreign policy, the party endorsed a pro-Western orientation (PiS 2001a, PiS 2001b). What is surprising from today's perspective is that there was originally no strong identification of the party with the Catholic Church, although the manifesto did, of course, mention Christianity. This started to change around 2005 (see below for details).

Also characteristic of the founding manifesto was PiS's emphasis on several specific topics, such as decommunisation, especially by proposals to adopt lustration legislation and ensure better law enforcement. This reflects the fact that PiS originally did not have a polished and visionary project; rather it sought to mobilise against the ex-communist left. A change started to shape up after 2003, when a more comprehensive vision was born of establishing a Fourth Polish Republic (IV Rzeczpospolita), which was to replace the Third Republic that had existed since 1989. Although in its more recent party documents PiS does not explicitly endorse the Fourth Republic project and some of its important elements are obviously no longer topical (especially the idea of strengthening the position of the president), the influence of this project on the party's policies continues to be apparent. In some of his speeches, Jarosław Kaczyński in discussing the radical changes made since the 2015 elections made references to the project (see the dimension of support for the regime below).

\section{The socio-economic dimension}

Characteristically, PiS anti-communism is also projected into the socio-economic sphere. In its founding documents, the party highlighted the enduring pathologies of the communist regime, linked largely with corruption and political clientelism. The consequence was an insufficiency of public resources. The instruments proposed by PiS to improve the state's financial efficiency and transparency included the publication of lists of people in tax arrears (the party did not bother with the issue of personal data protection; PiS 2001a). The party programme also suggested enlarging the province of the public prosecutor- 
-general, who would be turned into a kind of universal representative of the state in judicial matters, with the power to act as an enforcement officer to collect debts. Such a change would greatly increase the influence of the state.

On the one hand, PiS supported private ownership, small and medium-sized enterprises, and tax decreases for physical and legal persons. On the other, the party was critical of banks, calling for their greater regulation, as well as regulation of the stock market and large enterprises, because 'the stock market destabilises the economy more than it creates capital' (PiS 2001b). The party also wanted to maintain state influence in crucial businesses, e.g. the PKN Orlen petrochemicals company, the Polish State Railways and the Polish Post (PiS 2006), and sharply criticised neo-liberal approaches (PiS 2014a). The party continuously expressed support for Polish businesses and argued that there was a need to 'rationalise foreign investment' (PiS 2001b) and introduce sectoral taxes. Both measures were evidently largely aimed against the influx of foreign capital. This was accompanied by appeals to national and social solidarity.

Manifesto promises deployed ahead of the 2015 elections, such as free medication for the over-75s, the lowering of the pension age and an extensive pro-family programme, Family 500+, which proposed what was in Polish terms a large financial contribution per child, were certainly attractive to the socially disadvantaged (PiS 2014a; Kancelaria Prezesa Rady Ministrów 2015). After the elections, these promises became political reality, and thanks to this agenda PiS was able to fill the space that was previously occupied by the ex-communist left. In the 2019 election manifesto, this agenda was broadened further: promises were made of free medication for pregnant women, no income tax for the under-26s, increases in the minimum wage (up to 4,000 zloty/about $€ 1,000$ per month in 2023) and the sustaining of a regular, so-called thirteenth pension payment. This was first paid by the PiS government in 2015 (PiS 2019). In PiS rhetoric, these measures were about achieving the Polish welfare state and rectifying the insensitivities of the transformation era after 1989. Opinion polls ahead of the 2019 elections showed that social programmes were among the crucial issues that interested voters most (Tematy kampanii 2019). The fact that PiS took nearly half of the vote suggests that the party opted for a strategy that was electorally efficient.

Characteristic of the PiS profile in this dimension overall is an orientation towards ensuring economic growth while favouring the nationalistically motivated protection of domestic entrepreneurs, maintaining state ownership in major enterprises and what is in Polish terms a grandiose public welfare policy oriented towards various social groups. The important, even essential, role of the state in all this evidently goes far beyond the 'conservative norm' today. PiS is certainly not an economically liberal party; rather, it opposes the liberals with hostility. In its socio-economic positions, it is close in many respects to the old National Democrats, although the latter have never considered an extensive welfare state, given the poor economic conditions of interwar Poland. 


\section{The religious dimension}

The public endorsement of a strongly Catholic public profile, and developing links between PiS and the Catholic Church, were gradual. The earliest manifestos were vague in this respect. A change started to shape up after several years, in connection with the 'Fourth Republic' project and its fundamental document, the Catholic Constitution, which made Catholicism the exclusive religion, seeking to project it into public social life, and hoping to rectify what were seen as the weak aspects of the 1997 constitution. The introductory preamble was unambiguous: 'in the name of God Almighty'; this was complemented by a 'PiS commitment to Christian values' (PiS 2005a). In this document, Christianity is understood in a broad as well as a personal sense, as one of the foundations of the nation and society. The intensity of the feeling is evident from this formulation: 'for believers, Catholicism is truth; for non-believers, it represents civilisation.' (PiS 2005a) Faith is seen as a value important for the cultural and political organisation. In a country where religious belief and God are still considered by many as a natural part of life, and where few are openly atheist, such an orientation makes sense.

This is accompanied by unqualified support for the traditional arrangements of the family and marriage, seen as a union of a man and a woman. There is a continuous line, linking a number of manifestos including the most recent one (PiS 2019). The party describes the family as 'the basic unit of society with unquestionable rights.' (PiS 2005b) Beyond the nation, the family is the key community, through the prism of which PiS views society. By contrast, the party describes 'gender ideology' as dangerous, and rejects the demands made by LGBT minorities. PiS sees these as manifestations of 'social demoralisation [...] which causes problems in many areas of social life' (PiS 2005a).

Similarly, PiS sharply rejects abortion and strongly supports the legal protection of life including unborn life. Characteristically, of human rights PiS attaches the greatest importance to the right to life; followed by the right to freedom and the right to equality rooted in human solidarity. The party also aims to create a moral order in society (PiS 2005a, PiS 2005b, PiS 2014a, Murphy 2017).

The party assigns a major role to the Catholic Church in the building of Polish society. In the era of a communist Poland in particular, PiS believes, the Church served as 'a pillar of Polishness and a substitute for the non-existent sovereign state' (PiS 2014a). This quotation reflects the historical blending of Polish national and religious identities; what the party adds is a major emphasis on the importance of Catholicism and the Catholic Church. Catholic teaching, together with tradition and patriotism, are defined by PiS as 'mutually interlinked in the construction of the political identity of the nation' (PiS 2014a). The Catholic Church is to have an important position not just in the private, but also in the public sphere. In its programme, the party pledges to 
maintain the Church's position, because it sees it as having a clearly positive society-wide impact.

The alliance with some in the Catholic hierarchy can be seen today as one of the defining characteristics of PiS, as well as a source of its success. Particularly important for the party are its links with the influential Radio Maryja, its director, Father Tadeusz Rydzyk, and other associated media. It was in part thanks to this that, after the collapse of the ultra-Catholic League of Polish Families, PiS has taken virtual control of the right wing of Polish politics since 2007 (cf. e.g. Pankowski 2010: $187-189){ }^{8}$

Catholicism is evidently an important - perhaps the most important - element of the party's conservative identity. Religion cannot be seen as a supplement to the PiS identity, but as a fundament of many of its core values. It influences the party's views of how society should be arranged and on the family and human rights. In this respect, PiS again deviates significantly from the much more moderate approach towards Christianity and the churches that prevails among contemporary conservatives in general. Yet for the ancient authoritarian continental conservatism of the 19th century and the first decades of the 20th, the strong emphasis on God and Christian dogmatism was, by contrast, typical. Interestingly, the increasing importance of Catholicism in the PiS party identity parallels a similar development in the interwar Polish National Democrats. The party's overall dogmatic conservative-Christian orientation, combined with its protectionism in the socio-economic sphere as described above, has created a rather peculiar social conservatism in contemporary Europe. Its characteristics are completed by the other dimensions, including the cultural and ethnic dimension, to which we now turn.

\section{The cultural and ethnic dimension}

The topic of the Polish nation resonates strongly in the PiS programme, and is deemed crucial for the contemporary state and society. The nation is understood as a community in a cultural, political and historical sense (PiS 2014a, PiS 2019). Beyond the family, PiS emphasises the nation as the fundamental political and social unit. This understanding is projected into the party's critique of the Third Republic. PiS argues that 'the nation is divided into those who came to terms [with the change wrought by transformation] and the millions who found themselves on the margins' (PiS 2001b). Characteristically, PiS claims that 'Poland must be a state for Poles' (PiS 2001b). This implies an ethnic conception of the nation, and its delimitation by excluding minorities.

8 The party's only competitors are the radical-nationalist Kukiz'15, established by the rock singer Pawet Kukiz, which won seats in the national parliament in the 2015 elections, and the Confederation Liberty and Independence, which won parliamentary representation four years later. 
In more recent documents, PiS claims that 'it does not define the nation in the ethnic sense' (PiS 2014a). However, the quotations above, as well as the party's harsh anti-immigration position during the refugee crisis and the openly anti-Semitic positions of some (albeit marginal) segments of the party, signify that PiS is close to the ethnic conception (cf. PiS 2014a; Cieński 2017; Krzyżanowski 2018). Similarly, the party's sharp rejection of LGBT minorities indicates that it does not see them as part of the nation. It is interesting to note in this context the party's view of the millions of Poles abroad, who problematise the party's understanding of 'Poland as the state of the [whole] Polish nation' (PiS 2001b). The party says that cooperation with the Polish diaspora needs to improve; this is linked with the importance conservatives attach to the unity of the community, and the role of national identity. PiS deems it necessary to 'build a strong and meaningful community' (PiS 2014a).

In summary: PiS places enormous emphasis on the unity of the nation and national homogeneity on an ethnic basis, and wants to defend or support this both inside and outside Poland. The party employs strong nationalism which goes substantially beyond the common patriotic conservative positions. In the $\mathrm{PiS}$ view, minorities are not an element that ought to be supported. A traditional view of the shape of society prevails in the social-cultural area as well. As we shall see below, the radical nationalist orientation has significant repercussions in the dimension of support for the regime.

\section{The dimension of support for the regime}

PiS emphasises a notion of the greater efficiency of the state. The aim is a state that will be strong externally and internally; will be able to provide security, command respect and promote national values. The party considers the Polish state since 1989 as 'weak and powerless when it should defend the interests of the individual, the family, society and the nation' (PiS 2014a). The state with a clear authority is supposed to rely on a moral and historical legitimacy, and this is accompanied by references to the interwar Second Polish Republic in particular (PiS 2001a; PiS 2001b; PiS 2014a).

As noted above, the PiS position on the regime of the Third Polish Republic (established since 1989) is very critical. The party considers the elites the greatest problem; hence in its founding manifesto it called for the 'removal of dishonest politicians' reliant on businesses and 'organised crime' (PiS 2001a). The cleansing of politics should start with a clear break with the PRL legacy. Among the measures proposed by PiS were: allowing access to communist archives; asset declarations for public officials; and setting qualification criteria for people holding public offices, including elected offices (PiS 2001a, 2001b). In the spirit of its name (Law and Justice party), PiS also established itself on the issues of order and security, proposing to strengthen the powers of the police 
and make sentencing harsher. The Kaczyński brothers also spoke about reintroducing the death penalty, though this was never explicitly mentioned in any manifesto.

The emphasis on decommunisation, especially by dealing with PRL cadres through a wide-ranging lustration policy, was one of the main topics of the PiS government in 2005-2007, but the policy was halted by the Constitutional Court (Dudek 2016: 580-582). The project of the Fourth Polish Republic dates to the same period. It can be considered an attempt to achieve a political breakthrough, and a transition from the parliamentary Third Republic to a regime with a strong executive, which would in fact be a semi-presidential system. ${ }^{9}$ The vision of a strong presidency was later abandoned, perhaps because following the death of his brother Jarosław Kaczyński failed in the presidential election, and later gave up the ambition of ever occupying that office. Before the 2015 elections, the party documents pushed the earlier emphasis on changing the system into the background (this was largely for tactical reasons) and instead only mentioned 'change to various parts of the state apparatus' (PiS 2014a).

Yet the efforts at centralisation, the enormous concentration of political power, and the disruption of the system of checks and balances between the legislative, executive and judicial branches, which were contained in the project of the Fourth Republic, endured. These proposals served precisely as the blueprint for change that PiS set in motion after coming to power in 2015. It is also worth noting that the project of the Fourth Republic emphasised its nationalist and conservative aspects. One of the state's fundamental tasks was to 'protect the nation and its continuity for future generations' (PiS 2005b). This is a nationalist vision that PiS projected during the second half of the 2010s into many aspects of its governance, including the transformation of public service television and radio.

Here we need to note PiS's views on media pluralism. Before coming to power in 2015, the party often complained of the media's disfavour. The programme spoke of the 'necessity to rebuild' media plurality (PiS 2014a). The greatest attention was paid to public service broadcasters, which, the party argued, should uphold national traditions and promote education in history (PiS 2014a). In a speech she made when coming to office in late 2015, Prime Minister Beata Szydło explicitly spoke about the 'mission' of public service media (Kancelaria Prezesa Rady Ministrów 2015). This was followed by a lightning-fast change of personnel and structure, which turned public service radio and television into

9 To give the reader an idea of what this system would involve: the president would have the power to reject minister and prime minister candidates; he could chair the government in extraordinary cases (what these are would actually be defined by the president himself); would ratify and revoke international treaties; and within six months of the presidential election could dissolve parliament. The project of the Fourth Republic did not explicitly mention any powers of parliament beyond oversight of the government and the option of expressing no confidence in it. The proposal did not formally weaken the position of the government, but in practice it would be limited to executing domestic and foreign policy, and would not set those policies. This again reflects the idea that the president is the key player who decides strategic matters (PiS 2005b). 
government mouthpieces. This is one of the reasons why the media in Poland today are deemed only partially free (cf. Freedom House 2018).

Before coming to power, PiS was strongly critical of the judiciary. Not only did the party oppose the continued service of many judges who had started their careers under the PRL; it also criticised low efficiency and corruption, which, the party argued, created injustice. Yet PiS denied the very principle of judicial independence. Its programme was telling in this respect: 'the people cannot be denied influence over the functioning of this third power' (PiS 2014a). As PiS sees it, courts of law should be to serve society, not to dispense justice. The party aimed for stronger control of the judiciary by the sovereign (the people), via its parliamentary representatives, i.e. it sought to bind the judiciary with the legislative, and, derivatively, with the executive. The same problematic logic commanded the efforts to merge the Ministry of Justice with the Office of the General Prosecutor - this was de facto aimed at subjugating the latter (PiS 2014a). ${ }^{10}$ As with the plans for public service broadcasters, these visions came to be implemented after the 2015 elections, when the offices of the minister of justice and general prosecutor were combined, the importance of the Constitutional Court was drastically limited and its independence curtailed, the retirement age of Supreme Court justices was lowered, and retirees were replaced with people close to PiS (cf. O’Neal 2017: 39-42; Sadurski 2018; Council of Europe 2018).

Characteristically for the continuity in PiS positions, irrespective of criticisms voiced inside and outside Poland, in the 2019 election manifesto the measures that had already been taken were described as the 'policy of good change' and the party proclaimed its intention to conclude its reform of the judiciary, including, for instance, changes to the extent of judges' immunity (PiS 2019). What this would entail precisely was unclear. However, the developments in the judiciary are subject to the pressures exerted by the European institutions to some extent (e.g. Cieński and Wanat 2019).

Thus, in the dimension of support for the regime, PiS established itself as a stringent critic of the liberal-democratic system. The party argues that the character and principles of the post-1989 political system are false. Following the death of Lech Kaczyński, which meant the de facto end of the semi-presidential project of the Fourth Republic, PiS adjusted its vision towards a populist democracy. In this vision, the democratic legitimacy of parliament, derived from elections, stands above everything else. In practice, this approach led to the dismantling of some pillars of liberal democracy. This has been most conspicuous in the radical interference with the judiciary and public service broadcasters. In this dimension, PiS has nothing in common whatsoever with the evolutionary adaptability of moderate conservatism, and goes entirely against its spirit.

10 Here it needs noting that this problematic arrangement was still in place in Poland for quite some time after 1989. 


\section{Urban vs. rural dimension}

The PiS position in this dimension allows us to see the party as an advocate of the countryside and rural interests. In its very first documents the party said it would endeavour to 'equalise living standards and development in the cities and in the country' (PiS 2001b). The importance of this dimension is well illustrated by the party's special agricultural programme of 2014, which noted the rural identity and understood agriculture as a strategic segment of the economy (cf. PiS 2014b, PiS 2019). This is not just because the proportion of people employed in agriculture is still high in Poland, but also because the greatest PiS electoral strongholds are the eastern and south-eastern parts of the country, which are more rural and traditionalist. Also important is the fact that in its rhetoric, PiS often links its main rival, PO, with a liberal urban environment that fails to listen to rural concerns.

However, PiS does not explicitly advocate a rural lifestyle, though it considers it necessary to conserve certain aspects of the countryside, which 'ought to preserve the traditional built environment and the way rural spaces have been formed' (PiS 2014b). Rural development should be 'based on family farms' (PiS 2014a).

This dimension demonstrates particularly well PiS's willingness to push market principles into the background. PiS promoted instruments such as 'green diesel' - not fuel from renewable sources but tax exemption for fuel used by farmers - and defends massive subsidies which the European funds have provided to Polish farmers. Another example of the party's emphasis on rural interests was its advocacy for keeping the ownership of land in Polish hands after the end of the so-called 'transition periods' that Poland negotiated when it joined the EU (European Commission 2019; PiS 2014a; PiS2014b). Likewise evident in this dimension are a focus on redistribution and an effort to provide social concessions to various agrarian groups. For instance, in the 2019 election manifesto the party promised to top up small farmers' expenses and to stabilise crop prices (PiS 2019).

Overall, for PiS the countryside is part of the conservative vision of the world, linked with tradition, faith and family, as well as an instrument the party can use to define itself in opposition to PO, which is sometimes portrayed as a proponent of metropolitan interests. Rural areas are seen as supporters of the traditional arrangement of society, yet on many issues the PiS position is rather pragmatic. The party highlights problematic aspects of the countryside, and assumes at least a partial accommodation of contemporary trends. The state is supposed to play an important role in all this, but the party does not have a comprehensive vision for the countryside's future, and largely seeks to respond to its current needs and expectations. 


\section{Foreign policy dimension}

The party argues that its fundamental principle in this dimension is to pursue and protect the 'Polish raison d'état and national interest' (PiS 2001b; PiS 2014a). NATO and the EU are deemed the most important supranational institutions. The role of the United Nations is seen as less important, despite efforts to become a non-permanent member in the Security Council (PiS 2014a), which Poland achieved in 2018. Particularly important - and in the context of Polish 20th-century history, entirely understandable - is the emphasis on ensuring Poland's security. Here PiS highlights the country's sensitive geopolitical position (PiS 2014a) and proposes (1) strengthening and modernising the armed forces and gradually increasing defence expenditure (up to 2.5 per cent of GDP in 2030) and the number of active personnel; and (2) continuous support for Polish involvement in trans-Atlantic structures, with 'our membership of NATO' serving as the foundation (PiS 2001b). Poland's strategic partnership with the USA is particularly important for point (2). Tellingly, a recent manifesto included the objective of establishing a permanent American base in Poland (PiS 2019).

The party's representatives often assumed the position of supporters of the USA, for example by backing the American engagement in Iraq, where Poland had a relatively large military contingent. As far as EU projects are concerned, $\mathrm{PiS}$ is formally inclined towards 'closer cooperation of states on the question of security', without this creating a fully-fledged alternative to NATO (PiS 2014a). Submission to the EU's common foreign and security policy is out of the question for the party.

With respect to European integration, PiS is a soft Eurosceptic (Taggart and Szczerbiak 2002), and this is informed by the elements of the party's identity already described. Since its inception, the party has placed emphasis on national aspects within the integrated Europe, because 'the basic premise must be the preservation of the nation state' (PiS 2001b). PiS admits that the EU has had many successes, and thanks to its original idea it has 'achieved a common market, freedom of movement...' (PiS 2014a). Yet PiS rejects anything that goes beyond the framework of general cooperation and economic integration. It is very critical of closer integration and has long rejected the option of turning the Union into a federation, emphasising the issues of 'defending national identity, tradition and culture' (PiS 2014a). The PiS position is nonetheless pragmatic, and its programme notes the positive effect European funds have had on agriculture in particular.

The PiS position on Russia has undergone an interesting development; historically, Russia was a major threat to Poland. At its inception, the party was quite neutral, emphasising the necessity of maintaining 'good neighbourly relations' and of making efforts to 'overcome negative historical experiences', although the programme noted certain risks (PiS 2001b). However, the party 
gradually became tougher, largely in response to Russian policy (Russia's resistance to the installation of the US anti-missile system in Poland, the Russian attack on Georgia in 2008, etc.); and the Smolensk crash was very influential as well. A more recent PiS manifesto proposes to establish interaction with Russia by 'returning to realistic and reliable partnership relations [...] based on mutual respect', but it highlights issues that are seen as conflictual. In particular, PiS argues that the accession of Ukraine and the Caucasian countries to NATO needs to be supported, and returns to the 2010 aircraft crash noting the 'necessity of it being explained in full' (PiS 2014a).

From the viewpoint of conservative thought, historical experience provides the grounds for Polish membership of NATO, because the aid that Western Europe alone could provide would be insufficient to defend Poland. During the era of the Cold War against the Soviet Union, NATO managed to ensure the security of the Western world. The USA is evidently Poland's only ally to have sufficient capacities at its disposal that could be deployed to aid Poland should it be attacked. The PiS position is therefore linked not only with its support for NATO and the USA - which are common among conservatives generally - but also with the fact that there is no credible alternative that would be able to guarantee security and the primary national interest: the survival of an independent and sovereign Poland. There is a broad social and political consensus about this in Poland. The PiS position on the EU is typically national-conservative. The party prefers the nation state over closer supranational cooperation, which it sees as limiting in certain respects, and even dangerous in that it transfers some powers to a level which the representatives of the Polish state cannot control. This disrupts one aspect of the conservative-realist conception of the state as a sovereign and independent territory. However, PiS does not propose a clear alternative arrangement for the EU, even if there is an evident effort to highlight regional groupings such as the Visegrád Group (or Visegrád Four, V4) or the informal Three Seas Initiative (cf. PiS 2019).

The core of the PiS position on Russia is not just conservative, but informed by long-term relations between the two countries - which have been far from ideal - and in particular by the dangerous past. From a conservative position, guardedness is warranted by Russia's specific approach towards the international system. Russia does not respect this system, or its approach is unpredictable, and, from a conservative perspective and that of the Polish national interest, this is clearly undesirable and threatening (cf. e.g. Reeves 2010).

\section{The post-materialist dimension}

Some aspects of this dimension have already been suggested above. As far as PiS's approach towards the functioning of the state is concerned, there is an evident tendency towards greater centralisation, although this does not ex- 
plicitly exclude the possibility of citizens participating in decision making via referenda, and there are occasional mentions of strengthening the position of local government. Yet in the party's founding manifesto, there was the contrary idea of 'stronger oversight by the voivodeship [region] over local government' (PiS 2001a). The party's ideas about resolving many issues are often similar: to create an umbrella office at the central level (the Central Anti-Corruption Bureau, the Chief Inspectorate of Environmental Protection, etc.). Control from the centre is supposed to facilitate better functioning in a number of areas. PiS aspires to create a state that exercises numerous functions and is active (cf. PiS 2001a; PiS 2001b; PiS 2014a).

PiS is clearly a pro-materialist party, which has long favoured economic growth and a decrease in unemployment. The economy and the advantages of development are among the major themes of the party's programme, which emphasises that these must benefit every member of society. Post-materialist values are explicitly considered as secondary. The programmes tend to contain generic and platitudinous mentions of 'the need to protect natural resources and prevent their unlimited exploitation' (PiS 2001b), or of efforts at 'economic development while respecting our nature and landscape' (PiS 2014a). More specific positions on environmental protection tend to be rare. The nationalist economic orientation is apparent even here, in that the party wants to preserve state ownership of (or influence in) forests and water resources.

The PiS identity in this dimension is revealed by the harsh criticism the party made of the PO-led government for adopting the EU climate and energy package. Similarly, PiS justifies the questionable exploitation of natural resources, such as when the PiS government in 2018 permitted logging in the Białowieża Forest. The party is essentially satisfied with some of the changes in environmental protection that have been adopted since 1989. When it is positive about environmental protection, it is largely with respect to non-problematic questions such as landscape reforestation (Kancelaria Prezesa Rady Ministrów 2017), or situations where it must respond due to the pressure of circumstances or public criticism. Examples include the objective of pollution reduction by subsidies for environmentally-friendly boilers (PiS 2019).

In summary, by its emphasis on centralisation and the very active, even all-pervading, role of the state, PiS comes into conflict with Anglo-Saxon conservatism, which is much more moderate and cautious in this respect. Post-materialism is unimportant for the party, and this contrasts with the more common conservative efforts to achieve a better balance between the economy and the environment. The fundamental PiS positions in this and other dimensions are summarised in Table 2. 
Table 2: PiS positions in the ideological dimensions

\begin{tabular}{|l|l|}
\hline Dimension & PiS position \\
\hline Socio-economic & $\begin{array}{l}\text { Support for business, but a tendency to regulate the market strongly } \\
\text { via the active role of the state; a nationalist motivation and extensive } \\
\text { redistributive social programmes are evident. }\end{array}$ \\
\hline Religious & $\begin{array}{l}\text { Catholicism as the foundation of Poland; a privileged role for the Catholic } \\
\text { Church in society and public life; emphasis on the traditional family. }\end{array}$ \\
\hline Cultural and ethnic & $\begin{array}{l}\text { Emphasis on national homogeneity and unity based largely on an ethnic } \\
\text { conception of the nation; minorities are tolerated; efforts to strengthen } \\
\text { cooperation with Poles abroad, with the notion of a shared community. }\end{array}$ \\
\hline Support for the regime & $\begin{array}{l}\text { Criticism of the liberal-democratic system, concentration of power, lack of } \\
\text { respect for the separation of powers, a radical reconstruction of the state } \\
\text { in a national and Catholic spirit. }\end{array}$ \\
\hline Urban vs. rural & $\begin{array}{l}\text { Efforts to preserve some characteristics of the countryside and a certain } \\
\text { (limited) emphasis on a rural identity; efforts to present the party as an } \\
\text { advocate of the rural areas of the country are combined with a pragmatic } \\
\text { approach. }\end{array}$ \\
\hline Foreign policy & $\begin{array}{l}\text { Determined support for NATO membership and emphasis on the alliance } \\
\text { with the USA; reservations about greater EU integration; antagonistic and } \\
\text { mistrustful relationship with Russia. }\end{array}$ \\
\hline Post-materialist & $\begin{array}{l}\text { Clear pro-materialist orientation, post-materialism is wholly secondary; } \\
\text { centralisation of the state. }\end{array}$ \\
\hline
\end{tabular}

Source: Authors.

\section{Conclusion: a Catholic-nationalist rebuilding of Poland}

In summing up the answers to the questions which we posed at the beginning of this article, it is best first to address the dynamics of PiS ideology, that is, how it changed over time. Over nearly two decades, party ideology was modified to some extent; in particular, it was broadened. Originally, PiS was a narrowly focused anti-communist entity, and this was complemented with anti-corruption appeals and an emphasis on law and order. Gradually, the party identity evolved into a form the most important components of which are Catholicism and, linked to this, strong emphasis on the role of the Catholic Church; an ethnically conceived nation; and a vision of a strong and active state able to form society in a national spirit. This has been accompanied by a harsh negation of the developments in Poland since 1989; support for the authority of soldiers and teachers in society; the leadership of Lech Kaczyński, understood in mythical and quasi-religious terms; and various conspiracy theories. The party sees society as comprising two fundamental building blocks of community: the nation and the family. The individual is very much pushed into the background in the PiS conception. Personality should be formed in the family, in the spirit 
of love for the nation and for Poland. The family is the most important unit in the country's day-to-day functioning, and, in the traditional sense, provides the fundament for the survival of the nation. This conception is close to a historical tradition that is particularly linked with the interwar National Democrats.

The relationship with history is very important for PiS, and this is projected into notions about the importance of historical education and the politics of memory. Apparent in the party's identity is its inspiration by patriarchal society, and its praise for certain historical periods and heroic deeds, such as resistance against Nazism and communism. The interwar Second Polish Republic is to serve as a model, and its values are to be enforced in Poland today. PiS does not distinguish between the parliamentary democracy up to 1926 and the authoritarian regime of Józef Piłsudski that followed. Here we can observe a connection with PiS's lack of respect for the principles of liberal democracy. It is also characteristic that, as in the era of the Piłsudski regime after 1926, since 2015 the actual locus of power has been translated outside the framework of constitutional institutions and into Jarosław Kaczyński’s party office.

The importance which PiS attributes to history and tradition is linked with an enormous emphasis on another community: the Catholic Church. The strong connection with the Church and faith implies a notion of society based on religious values and premises, and not entertaining relativistic morals or values. The party supports the preservation of the position of the Church, which has historically been important; its values and principles are seen as desirable and positive. On these points, $\mathrm{PiS}$ is similar both to the Polish National Democracy of the interwar era (and, more generally, to the ancient continental authoritarian conservatives), and to a specific strain of the contemporary conservative New Right, albeit one that is largely influential outside Europe. Its representatives include the Christian associations and groups that contributed to Ronald Reagan's political success at the turn of the 1970s and 1980s. (They were evangelical rather than Catholic, however.) This religious current has maintained its political influence, both during Reagan's presidency and subsequently, and has been an important force in the Tea Party, for instance.

PiS's notions of the ideal society and state are similar in many respects to the notions entertained by the US religious right. Society is not to be fragmented; its organisation is viewed in traditional terms, and PiS supports a fundamental role for the Church in public and private life. PiS corresponds to Gilles Kepel's (1996: 13) characteristic of this religious current: it is about 'rebuilding [society] on the basis of Christian principles', with an obvious messianic dimension. Through references to the dysfunctions of society and the state, Kaczyński's party has largely managed to control the public debate in Poland, which the party has focused on the nation, traditions, religious belief and solidarity. PiS is an actor that provides answers to this type of question, and is able to disqualify other actors that lack a similar strategy. This is linked with the vision of a state that 
supports re-Christianisation, but only has a weak link with democracy, as it is primarily based on disseminating the Catholic 'truth'. Hence PiS's close links with the dogmatic Catholic discourse, spread by Radio Maryja above all others. Thus PiS can be ranked alongside parties and groups with an Orthodox Christian, Judaistic or Islamic focus, which Kepel identified in the USA, Israel and the Muslim areas. In America, these activists are sometimes described as social conservatives (e.g. Haidt, Graham and Joseph 2009; Marietta 2012), and this label can be used in Poland too.

The link between PiS and the neo-conservative New Right is only partial, because it can be observed only as leading to the social-conservative, religious branch of the latter. Two points are noteworthy in this respect. First, both Reagan and Thatcher were characterised by a pro-market spirit and an emphasis on free economic competition, as well as by notions of limiting the role of the state to its indispensable functions. With PiS, an entirely opposite position is apparent, and the party's protectionist scepticism of the market is accompanied by efforts to build a strong state in many areas. Similarly, the emphasis on extensive social programmes, and the robust discourse of decreasing social differences would be unthinkable with US or British neoconservatives. In this area, earlier domestic influences, once apparent in Roman Dmowski's thought, evidently prevail in PiS. The party simply combines militant Catholicism, nationalism and socio-economic protectionism.

Second, the neoconservative right never aimed - under Reagan or Thatcher to destroy liberal democratic institutions once coming to executive power. In contrast to this, PiS political practice has been marked by its deployment of radical measures, destructive of existing institutions. This is accompanied by references to controversial, or even clearly autocratic, moments in Polish history, sometimes without any religious background. Jarosław Kaczyński pursued a concentration of power that is in many respects redolent of Józef Piłsudski's. This tendency of PiS goes beyond efforts to strengthen the authority of the state in the neoconservative sense, and has nothing in common with moderate conservative political reform, pushing PiS towards authoritarian conservatism.

Beyond the conservative slogans about the revitalisation of Poland, we can discern in the PiS programme and actual political practice a successful strategy of the pursuit of power, which is aimed towards a fundamental reconstruction of the state and society. In this context, how the party deals with the symbolic and emotive elements is often quite politically expedient. This can be seen from the examples of the Smolensk disaster and the exploitation of the figure of Lech Kaczyński. Outwardly, the party seeks to establish a tradition; but actually, the event and the tragically perished politician have served the party political strategy. But from a conservative viewpoint, a tradition cannot be imposed and created merely by regular repetition (cf. Scruton 1993: 51). 


\section{References}

Allen, David (1981): Modern Conservatism: The Problem of Definition. The Review of Politics 43 (4): 582-603.

Beyme, Klaus von (1985): Political Parties in Western Democracies. Aldershot: Gower Press.

Borowiec, Piotr - Sobolewska-Myślik, Katarzyna - Kosowska-Gąstoł, Beata (2016): Structures of Polish Political Parties in the Second Decade of the 21st Century. In Sobolewska-Myślik, Katarzyna - Kosowska-Gąstoł, Beata - Borowiec, Piotr (eds): Organizational Structures of Political Parties in Central and Eastern European Countries. Kraków: Jagiellonian University Press, 311-327.

Dančák, Břetislav (2002): Republika Polsko, in Fiala, Petr - Strmiska, Maxmilián, eds., Politické strany ve střední a východní Evropě: Ideově-politický profil, pozice a role politických stran v postkomunistických zemích. Brno: Masarykova Univerzita, 285-314.

Dudek, Antoni (1997): Pierwsze lata III Rzeczypospolitej (1989-1995). Kraków: Wydawnictwo Geo.

Dudek, Antoni (2016): Historia polityczna Polski 1989-2015. Kraków: Znak.

Hecke, Steven van (2008): Christian Democracy and Conservatism on Demography: Some Explorations. European View 7(2): 303-307.

Gallagher, Michael - Laver, Michael - Mair, Peter (2011): Representative Government in Modern Europe. Boston: McGraw-Hill.

Haidt, Jonathan - Graham, Jesse - Joseph, Craig (2009): Above and Below Left-Right: Ideological Narratives and Moral Foundations. Psychological Inquiry 20(2-3): 110-119.

Heywood, Andrew (2007): Political Ideologies: Introduction. Basingstoke: Palgrave.

Hendl, Jan (2008): Kvalitativní výzkum. Praha: Portál.

Hloušek, Vít - Kopeček, Lubomír (2010): Origin, Ideology and Transformation of Political Parties. Farnham: Asghate.

Jasiewicz, Krzysztof - Jasiewicz-Betkiewicz, Agnieszka (2018): Poland: Political development and data for 2017. European Journal of Political Research Political Data Yearbook 57(1): 227-235.

Kepel, Gilles (1996): Boží pomsta. Křest'ané, židé a muslimové znovu dobývají svět. Brno: Atlantis.

Koubek, Jiří (2007): Analýza polských parlamentních voleb 2007 a jejich konsekvencí pro stranický systém, Člověk: Časopis pro humanitní a společenské vědy. 15 December 2007. Available at http://clovek.ff.cuni.cz/ view.php?cisloclanku=2008121601\#4 (27 October 2019).

Kowalczyk, Krzysztof - Sielski, Jerzy (2005): Polskie partie i ugrupowania parlamentarne. Toruń: Wydawnictwo Adam Marszałek.

Krzyżanowski, Michał (2018): Discursive Shifts in Ethno-Nationalist Politics: On Politicization and Mediatization of the "Refugee Crisis" in Poland. Journal of Immigrant \& Refugee Studies 16(1-2): 76-96.

Kubát, Michal (2005): Demokracie v Polsku. Praha: Slon.

Lijphart, Arend (1990): Dimensions of ideology in European party systems, in Mair, Peter, ed., The West European party system. Oxford: Oxford University Press, 253-265. 
Łuczewski, Michał (2016): Polák-katolík: geneze. Jak chápat polskou výjimečnost, in: Koehler, Krzysztof et al., Pánbíčkáři. Odkud se vzal polský katolicismus? Brno: CDK - Ośrodek Myśli Politycznej, 125-152.

Lukowski, Jerzy - Zawadzki, Hubert (2003): A Concise History of Poland. Cambridge: Cambridge University Press.

Mair, Peter - Mudde, Cas (1998): The party family and its study. Annual Review of Political Science 1(1): 211-229.

Marietta, Morgen (2012): A Citizen's Guide to American Ideology: Conservatism and Liberalism in Contemporary Politics. New York: Routledge.

Markowski, Radoslaw (2019): Creating Authoritarian Clientelism: Poland after 2015. Hague Journal on the Rule of Law 11(1): 111-132.

Matyja, Rafał (2009): Konserwatyzm po komunizmie. Warszawa: Wydawnictwa Akademickie i Profesjonalne.

Matyja, Rafat (2015): Songs of Innocence and Songs of Experience: Polish Conservatism 1979-2011, in Kopeček, Michal - Wciślik, Piotr, eds., Thinking through transition: liberal democracy, authoritarian pasts, and intellectual history in East Central Europe after 1989. Budapest: CEU Press, 201-236.

Mlejnek, Josef (2011): Postavení prezidenta v Polsku, in Mlejnek, Josef, ed., Postavení hlavy státu $v$ postkomunistických zemích. Praha: Univerzita Karlova, 177-222.

Nałęcz, Tomasz (1994): Spór o kształt demokracji i parlamentaryzmu w Polsce w latach 1921-1926. Warszawa: Wydawnictwa Wyższej Szkoły Businessu i Administracji.

Nisbet, Robert A. (2011): Politický konzervatismus: sen a realita. Voznice: LEDA.

O'Neal, Molly (2017): The European 'Other' in Poland's Conservative Identity Project. The International Spectator 52(1): 28-45.

Osiecki, Jan (2010): Polaków rozmowy o polityce. Warszawa: Prószyński i S-ka.

Pankowski, Rafal (2010): The populist radical right in Poland. London: Routledge.

Pospíchal, Matěj (2017): Polska A, B i C? Volební geografie vybraných polských vojvodství. Středoevropské politické studie 19(3-4): 264-318.

Reeves, Christopher (2010): Reopening the Wounds of History? The Foreign Policy of the 'Fourth' Polish Republic. Journal of Communist Studies and Transition Politics 26(4): 518-541.

Sadurski, Wojciech (2018): How Democracy Dies (in Poland): A Case Study of Anti-Constitutional Populist Backsliding. Sydney: Law School, Research Paper No. 18/01. Availaible at: https:// papers.ssrn.com/sol3/papers.cfm?abstract_id=3103491 (29 October 2019).

Sadurski, Wojciech (2019): Poland's Constitutional Breakdown. Oxford: Oxford University Press.

Scruton, Roger (1993): Smysl konzervatismu. Praha: Torst.

O'Sullivan, Noel (2013): Conservatism. In: Freeden, Micael - Sargent, Lyman Tower - Stears, Marc, eds., The Oxford handbook of political ideologies. Oxford: Oxford University Press, 293-311. 
Szczerbiak, Aleks (2006a): Power without Love: Patterns of Party Politics in Post-1989 Poland, in: Jungerstam-Mulders, Susanne, eds., Post-Communist EU Member States. Parties and Party Systems. Aldershot: Ashgate, 91-124.

Szczerbiak Aleks (2006b): The Polish Centre-Right's (Last?) Best Hope: The Rise and Fall of Solidarity Election Action, in: Szczerbiak Aleks - Hanley, Séan, eds., Centre-right parties in post-communist East-Central Europe. New York: Routledge, 55-79.

Taggart, Paul - Szczerbiak, Aleks (2002): Europeanisation, euroscepticism and party systems: Party-based euroscepticism in the candidate states of Central and Eastern Europe, Perspectives on European Politics and Society 3(1): 23-41.

Šmíd, Jan (2008): Konzervatismus, Distance. Available at: http://www.distance.cz/rocnik-2008/3cislo/konzervatismus (27 October 2019).

Vincent, Andrew (2010): Modern political ideologies. Chichester: Wiley-Blackwell.

Wapiński, Roman (1989): Roman Dmowski. Lublin: Wydawnictwo Lubelskie.

Wojtaszczyk, Adam K. (2007): Political parties and party system, in Sulowski, Stanisław, ed., The political system of Poland. Warszawa: Elipsa, 87-95.

\section{Party materials, public opinion surveys, dailies and other sources}

Araloff, Simon (2005): Kaczyński Brothers: Movie Stars That Turned Politicians, Axisglobe.com (23 September): available at https://web.archive.org/web/20060427001319/http://www. axisglobe.com/article.asp?article= 394 (27 October 2019).

BBC Monitoring (2018): Positions of Polish Ruling Party's Top Politicians assessed (8 June): available at https://search.proquest.com/docview/2051554646?accountid=16531 (27 October 2019).

CEIC Data (2018): Poland Unemployment Rate: available at https://www.ceicdata.com/en/ indicator/unemployment-rate (27 October 2019).

CBOS (2014): Komunikat z badań CBOS (January 2014): available at https://www.cbos.pl/ SPISKOM.POL/2014/K_009_14.PDF (27 October 2019).

CBOS (2015): Komunikat z badań CBOS (January 2015): available at https://www.cbos.pl/ SPISKOM.POL/2015/K_010_15.PDF (27 October 2019).

Cieński, Jan (2017): Why Poland doesn't want refugees, Politico.eu (21 May): available at https:// www.politico.eu/article/politics-nationalism-and-religion-explain-why-poland-doesnt-want-refugees/ (27 October 2019).

Cieński, Jan - Wanat, Zosia (2019): 5 takeaways from the Polish election, Politico.eu (15 October): available at https://www.politico.eu/article/poland-pis-tougher-times-despite-winning-election/ (27 October 2019).

Council of Europe (2018): Poland - Opinion on the Draft Act amending the Act on the National Council of the Judiciary; on the Draft Act amending the Act on the Supreme Court, proposed by the President of Poland, and on the Act on the Organisation of Ordinary Courts (8-9 December): available at https://www.venice.coe.int/webforms/documents/?pdf=CDL-AD(2017)031-e (27 October 2019). 
Česká televize (2017): Sedmé výročí smolenské tragédie, která stále rozděluje polskou společnost, (10 April): available at https://ct24.ceskatelevize.cz/svet/2083197-sedme-vyroci-smolenske-tragedie-ktera-stale-rozdeluje-polskou-spolecnost (27 October 2019).

Foy, Henry - Wasik, Zosia (2016): Jaroslaw Kaczynski: Poland's kingmaker, Financial Times (26 February): available at https://www.ft.com/content/8238e15a-db46-11e5-a72f-1e7744c66818 (27 October 2019).

European Commisson (2019): European Structural and Investment Funds: Poland, (25 October): available at https://cohesiondata.ec.europa.eu/countries/PL (27 October 2019).

Freedom House (2018): Poland: Freedom of the Press 2017: available at https://freedomhouse. org/report/freedom-press/2017/poland (27 October 2019).

Kancelaria Prezesa Rady Ministrów (2015): Exposé premier Beaty Szydło, (18 November): available at https://www.premier.gov.pl/expose-premier-beaty-szydlo-stenogram.html (27 October 2019).

Kancelaria Prezesa Rady Ministrów (2017): Exposé premiera Mateusza Morawieckiego - stenogram, (12 November): available at https://www.premier.gov.pl/expose-premiera-mateusza-morawieckiego-stenogram.html (27 October 2019).

Karnowski, Michał - Zaremba, Piotr (2006): O dwóch takich: alfabet braci Kaczyńskich. Kraków: Wydawnictwo "M".

Łątkowska, Mirosława - Borowski, Adam (2016a): Jarosław Kaczyński, Encyklopedia Solidarności (17 April): available at http://www.encysol.pl/wiki/Jarosław_Kaczyński (27 October 2019).

Łątkowska, Mirosława - Borowski, Adam (2016b): Lech Kaczyński, Encyklopedia Solidarności (17 April): available at http://www.encysol.pl/wiki/Lech_Kaczyński (27 October 2019).

Murphy, Connor (2017): Poland's de facto leader slams president, wants to restore 'moral order', Politico.eu (28 July 2017): available at https://www.politico.eu/article/jaroslaw-kaczynskiandrzej-duda-veto-poland-de-facto-leader-slams-president-wants-to-restore-moral-order/ (27 October 2019).

New Internationalist (2007): Lech and Jarosław Kaczyński, New Internationalist.org (1 April): available at https://newint.org/columns/worldbeaters/2007/04/01/kaczynski (27 October 2019).

Newsweek Polska (2017): W trumnie prezydenta Lecha Kaczyńskiego znaleziono fragmenty ciał dwóch innych osob. Newsweek.pl (1 June 2017): available at https://www.newsweek.pl/ polska/spoleczenstwo/w-trumnie-lecha-kaczynskiego- odnaleziono-fragmenty-cial-dwoch-osob/yn3c9ry (27 October 2019).

Nizinkiewicz, Jacak (2019): Solidarność ramię w ramię z PiS, Rzeczpospolita.pl (5 April): avalable at https://www.rp.pl/Analizy/304049878-Nizinkiewicz-Solidarnosc-ramie-w-ramie-z-PiS.html (27 October 2019).

PiS (2001a): Manifest polityczny Prawo i Sprawiedliwość: available at http://www.piotrbabinetz. $\mathrm{pl} / \mathrm{pdf} / \mathrm{manifest.pdf}$ (27 October 2019).

PiS (2001b): Program Prawa i Sprawiedliwości: available at http://www.piotrbabinetz.pl/pdf/ programpis2001.pdf (27 October 2019). 
PiS (2001c): Referendum i kara śmierci, (6 August): available at http://old.pis.org.pl/article. php?id=1306 (27 October 2019).

PiS (2003): Jarosław Kaczyński: IV Rzeczpospolita - program naprawy państwa, (17 June): available at http://old.pis.org.pl/article.php?id=2679 (27 October 2019).

PiS (2005a): Polska katolicka w chrześcijanskiej Europie: available at http://old.pis.org.pl/dokumenty.php?s=partia \& iddoc=21 (27 October 2019).

PiS (2005b): Konstytucja Rzeczypospolitej polskiej. Projekt Prawa i Sprawiedliwości: available at http://old.pis.org.pl/download.php?g=mmedia \& f=projekt_konstytucji.pdf (27 October 2019).

PiS (2005c): Expose Kazimierza Marcinkiewicza przed głosowaniem w Sejmie nad wotum zaufania dla rządu, (11 November): available at http://old.pis.org.pl/article.php?id=671 (27 October 2019).

PiS (2006): Exposé Jarosława Kaczyńskiego, (19 July): available at http://old.pis.org.pl/article. php?id=4591 (27 October 2019).

PiS (2011a): Nowoczesna, solidarna, bezpieczna Polska. Program Prawa i Sprawiedliwości: available at http://old.pis.org.pl/dokumenty.php?s=partia \& iddoc=157 (27 October 2019).

PiS (2011b): Raport o stanie Rzeczypospolitej: available at http://old.pis.org.pl/dokumenty. php?s=partia \& iddoc=155 (27 October 2019).

PiS (2014a): Zdrowie, praca, rodzina. Program Prawa i Sprawiedliwości: available at http://old. pis.org.pl/dokumenty.php?s=partia \& iddoc=164 (27 October 2019).

PiS (2014b): Program rolny Prawa i Sprawiedliwości: available at http://old.pis.org.pl/dokumenty. php?s=partia \& iddoc=163 (27 October 2019).

PiS (2016): Statut Prawa i Sprawiedliwości: available at: http://pis.org.pl/dokumenty (27 October 2019).

PiS (2019): Polski model państwa dobrobytu. Program Prawa i Sprawiedliwości: available at http://pis.org.pl/dokumenty (27 October 2019).

Radio Poland (2018): Polish GDP growth to hit 4.2 \% in 2018: World Bank, Radiopoland.pl (28 April): available at http://archiwum.thenews.pl/1/12/Artykul/360945 (27 October 2019).

Subotić, Małgorzata - Stankiewicz, Andrzej (2001): Drugi po prezydencie. Rzeczpospolita (5 July 2001).

Tematy kampanii (2019): Najważniejsze tematy kampanii wyborczej. Sondaż dla „Faktów“ TVN i TVN24. TVN (24 August): available at https://fakty.tvn24.pl/ogladaj-online,60/wybory-parlamentarne-2019-sondaz-jakie-sa-najwazniejsze-tematy-kampanii,961142.html (27 October 2019).

Woźniak, Mikołaj (2019): Działacze Solidarności na listach Prawa i Sprawiedliwości. Legendarny związek to przystawka partii rządzącej? Gtos Wielkopolski (15 April): available at https:// gloswielkopolski.pl/dzialacze-solidarnosci-na-listach-prawa-i-sprawiedliwosci-legendarny-zwiazek-to-przystawka-partii-rzadzacej/ar/c1-14047251 (27 October 2019). 
Wprost (2010): NSZZ Solidarność poparła Jarosława Kaczyńskiego. Śniadek będzie zbierał podpisy, Wprost.pl (29 April): available at https://www.wprost.pl/193845/nszz-solidarnosc-poparla-jaroslawa-kaczynskiego-sniadek-bedzie-zbieral-podpisy.html (27 October 2019).

Adam Folvarčný is a a PhD candidate at the Faculty of Social Science, Masaryk University, Czech Republic. E-mail:427094@mail.muni.cz

Lubomír Kopeček is professor of political science at the Faculty of Social Studies, Masaryk University, Czech Republic. He specializes in comparative politics and various aspects of Czech politics. His most important publication is the monograph 'Origin, Ideology and Transformation of Political Parties. East-Central and Western Europe Compared' (with Vít Hloušek, Ashgate). ORCID: 0000-0003-2987-3035. E-mail:kopecek@fss.muni.cz. 